\title{
ORAL HYPOGLYCAEMIC DRUGS
}

*By J. D. H. Slater, M.A., M.B., M.R.C.P.

Medical Registrar, Middlesex Hospital, London

In 1955 Franke and Fuchs published clinical observations on the potent hypoglycaemic action of a sulphonamide, I-butyl 3-sulphanilyl urea, called carbutamide. $\dagger$ After extensive clinical trials in America, Canada and the United Kingdom carbutamide has been withdrawn from clinical use because of the high incidence of serious toxic effects. About 5 per cent. of 7,193 patients developed skin rashes, gastro-intestinal disorders, severe leucopenia, liver damage and generalized sulphonamide sensitivity reactions; eight patients died Io to 30 days after starting treatment (Kirtley, 1957).

In the past two to three years another sulphonylurea, tolbutamide, which lacks the p-amino group of the sulphanilamide derivatives, has been widely used without serious ill-effect in the treatment of mild diabetes mellitus of the adult type. How the drug acts is still uncertain, but its clinical usefulness is well established. This account will, therefore, be concerned chiefly with the mode of action and clinical applications of tolbutamide, but reference will be made to chlorpropamide, another sulphonylurea compound, and DBI, a biguanide, both of which have recently become available for clinical trial.

\section{Background}

Soon after the discovery of insulin by Banting in 1924, the hypoglycaemic effect of synthalin, a biguanide, was reported by Frank, Nothman and Wagner (1928) and studied later by Graham and Linder (1928). It was soon abandoned because it caused severe liver damage in therapeutic doses (Bertram, 1927). Extracts of plants have been used for a very long time as traditional remedies for diabetes in many parts of the world. Blueberry leaf extracts (Myrtillin) were investigated by Allen in 1927 and periwinkle, mistletoe and the nicker berry (long popular as 'doctor' bush teas in Jamaica) by Hugh-Jones in 1955. These, and other herbal remedies are either very toxic (especially to the liver) or have no hypoglycaemic

\footnotetext{
*'This article was received for publication in December 1958.

†Also known as $\mathrm{BZ}_{55}, \mathrm{U6987}$, Invenol and Nadisan.
}

effect. In large doses oestradiol benzoate may $\vec{\circ}$ reduce the hyperglycaemia of post-menopausal $\overrightarrow{\vec{\omega}}$ women with diabetes (Gessler et al., 1939). Injec- $\mathscr{\sigma}$ tions of dimercaprol sometimes cause a fall of blood and urine sugar concentration in diabetics re- 3 . ceiving large doses of insulin (Butterfield, 1957). Salicylates also lower the blood sugar level in patients with diabetes but only in amounts which $\underset{\omega}{\circ}$ cause side effects (Reid et al., 1957).

In 1942 Janbon and his colleagues discovered $\stackrel{+}{\infty}$ the dramatic hypoglycaemic action of a sul- $\frac{\text { ? }}{2}$ phonamide, p-amino benzene sulphonamido iso- propyl thiodiazole (IPTD), while assessing its 3 antibacterial properties in typhoid fever. A few of the patients died from hypoglycaemia. Between $\vec{\varphi}$ 1942 and 1946 studies on the mode of action of IPTD and other thiodiazole compounds in dog. and rabbits were made by Loubatière at Mons pellier. He was able to show that IPTD (I) cannot produce hypoglycaemia after removal of the whole pancreas, but will do so if as little as one-tenth of $\frac{0}{D}$ the gland remains, (2) is most effective when injected directly into the pancreatic artery or $\overrightarrow{\overrightarrow{0}}$ through the duct of Wirsung under pressure, (3) acts independently of the nervous system, (4) lowers the blood sugar in roughly inverse proportion to the blood sulphonamide level, and (5) raises the respiratory quotient after glucose administration. He postulated a pancreatotropic mechanism to explain these effects.

\section{Pharmacology of Tolbutamide}

Tolbutamide (Rastinon, Orinase, D.86o, U2043) is I-butyl 3p-tolyl-sulphonylurea. It has the following formula:

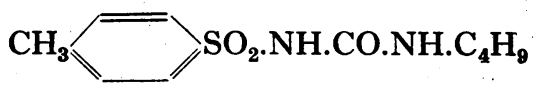

Unlike sulphanilamide derivatives it has no: p-amino group and, therefore, does not give theo Bratton Marshall reaction but it can be measured spectrophotometrically in alcohol or chloroform $\stackrel{\oplus}{+}$ extracts. It has no antibacterial activity and little $\underset{T}{T}$ or no effect on thyroid function (McGavack, 1957). Absorption from the gut is rapid and maximal $\stackrel{\mathbb{\Omega}}{\stackrel{\odot}{\circ}}$ blood levels are reached in about three hours. The $\mathbb{Q}$ 
biological half-life is four to eight hours with much individual variation (Baird and Duncan, 1957) and the drug is eliminated by the kidneys as the freely soluble carboxylic ester. This metabolite has no hypoglycaemic action but is responsible for to to 28 per cent. of the total blood tolbutamide level (Stowers, Mahler and Hunter, 1958). There is no danger of crystalluria. A white precipitate may develop on testing the urine for protein with sulphosalicylic acid when large amounts of carboxy-tolbutamide are being excreted.

Tolbutamide is supplied as $\frac{1}{2} \mathrm{~g}$. white tablets. The effective dose is $\mathrm{I}$ to $3 \mathrm{~g}$. per day, and increasing the dose above $3 \mathrm{~g}$. per day will not usually produce a greater fall of blood sugar concentration. Because it is rapidly excreted it should be given in divided doses every six to eight hours.

\section{Mode of Action}

Sulphonylurea compounds are now widely used in selected cases of diabetes mellitus. Already over 300,000 patients all over the world have been treated with tolbutamide. It is, therefore, most important that the mode of action is clarified and the relevant clinical and experimental data will be considered in some detail. Most of the earlier observations were made with carbutamide, but since there is no evidence to suggest that the sulphonylurea compounds have different modes of action, the data obtained with carbutamide will be included.

It is generally agreed that the sulphonylurea compounds will only produce hypoglycaemia in the presence of functioning pancreatic $\beta$ cells. Houssay and Penhos (1956) have confirmed that the presence of some pancreatic tissue is essential for the hypoglycaemic effects of these compounds in the same way that Loubatière showed that this was true of the thiodiazole sulphonamides. The sulphonylureas will reduce the fasting blood sugar level of intact and partially pancreatectomized animals or animals made mildly diabetic with alloxan. They will not do so after total pancreatectomy, either in animals or man, and they have no effect in animals made severely diabetic with alloxan. In humans the drugs are only effective in individuals who are able to produce insulin. They will reduce the fasting blood sugar concentration in non-diabetics and mild diabetics of the adult type but with very rare exceptions, the drugs will not act in patients with severe diabetes of the juvenile type. The pancreas of adult diabetics contains over 30 per cent. of the normal insulin content, while, in juvenile diabetics, little or no insulin can be extracted from the gland (Wrenshall and Best, 1956). Similarly, insulinlike activity is readily detected in the plasma of adult diabetics but generally cannot be found in
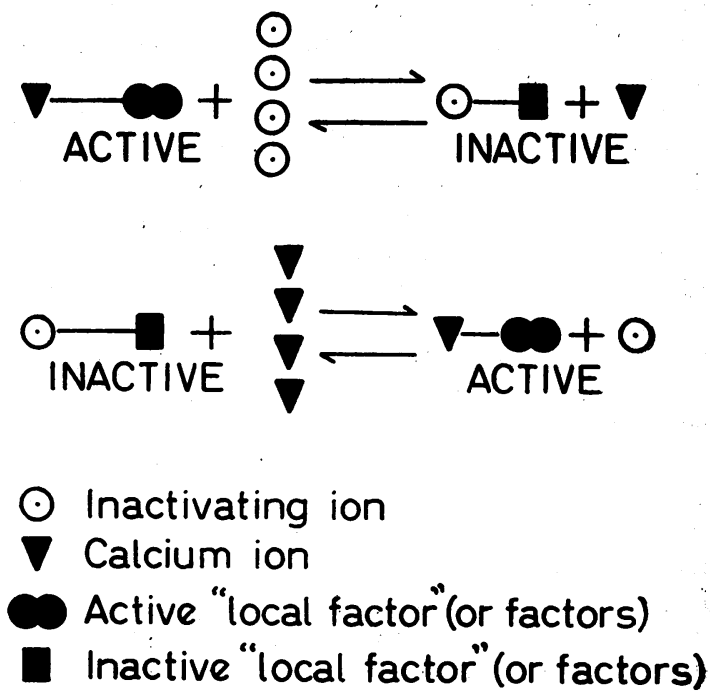

the plasma of patients with the juvenile form of the disease (Bornstein and Lawrence, I95I).

After evisceration in dogs (Fritz et al., 1956; Houssay et al., 1957), rabbits (Wick, Britton and Grabowski, 1956) and rats (Lang and Sherry, 1956) the drugs will not cause hypoglycaemia. Like insulin, removal of the pituitary or adrenal glands increases the hypoglycaemic effect, but, unlike insulin, hypophysectomized dogs are less sensitive than adrenalectomized animals (Houssay et al., 1956). In man, Fajans and his colleagues have shown that the drugs are active in patients with panhypopituitarism and Addison's disease both before and after replacement therapy with hydrocortisone. The hyperglycaemic response to adrenalin is unaffected and the rise of blood sugar level following injected glucagon is not inhibited in man (Fajans et al., 1956) or rabbits (Berthet et al., 1956).

From these results the following conclusions can be drawn concerning the mechanism by which the sulphonylurea compounds lower the blood sugar level: (I) they do not have a direct insulin-like action on peripheral tissues, ${ }^{*}(2)$ the presence of an insulin-containing pancreas is essential, (3) they do not act by reduction of glucagon secretion or by tissue antagonism of glucagon, and (4) inhibition of hormonal insulin antagonists from the pituitary or adrenals is not the mechanism.

We are left with three plausible ways of explaining the hypoglycaemic effect of the compounds: (a) the pancreas is stimulated to produce more

*Lundbaeck, Nielsen and Rafaelsen (r958) claim to have shown that in vitro tolbutamide slightly increases glucose uptake by the rat diaphragm. This is unconfirmed and contradicts earlier work using similar methods (Recant and Fischer, 1957; Cahill et al., 1957). 
insulin, (b) the rate of endogenous insulin destruction is diminished, and (c) hepatic glucose release and/or production is depressed.

(a) Liberation of insulin from the pancreas was first suggested by Loubatière to explain the hypoglycaemic effects of IPTD and other thiodiazole sulphonamides. In cross circulation experiments he was able to show that when IPTD was injected into a normal dog whose pancreaticoduodenal vein was anastomosed to the jugular vein of a depancreatized dog, the blood sugar level of the diabetic animal was depressed. Pozza and his coworkers, in similar experiments with intact animals, have demonstrated that, following intravenous carbutamide, the blood sugar level of the recipient animal could be lowered by the donor's pancreatic vein blood, but not by blood from the donor's mesenteric vein. Direct perfusion of the pancreas with tolbutamide via the right gastroepiploic branch of the gastroduodenal artery has been performed by Colwell, Colwell and Colwell. They have shown a greater fall of blood sugar level by this route than by injection into the femoral vein, but they were unable to produce hypoglycaemia by pancreatic injection in doses which were too small to be effective when given peripherally.

The response to tolbutamide appears to be proportional to the insulin content of the pancreas. Mirsky, Perisutti and Gitelson have shown in dogs that pre-treatment with growth hormone, which is known to deplete the pancreas of insulin (Campbell et al., 1953), will reduce the acute hypoglycaemic effect of tolbutamide. Similarly, prolonged fasting, which also reduces the insulin content of the pancreas (Best, Haist and Ridout, 1939), will diminish the hypoglycaemic response. Dulin and Miller have shown that after hypophysectomy in rats the amount of insulin in the pancreas falls to about half the pre-operative level at four weeks, and they claim that sensitivity to tolbutamide diminishes correspondingly. In humans, the rate of fall of blood sugar concentration following a single dose of tolbutamide ( $\mathrm{g}$. intravenously) can be used as a diagnostic test for mild diabetes (Unger and Madison, 1958). In normal people the fall of blood sugar level is more rapid and more profound than in patients with mild diabetes.

Morphological studies of the pancreatic islet tissue in animals show degranulation of the $\beta$ cells with swelling of their nuclei after the administration of large amounts of tolbutamide or carbutamide; the islets increase in size and number and mitoses are more frequent (Ashworth and Haist, 1956; Pfeiffer et al., 1957; Von Holt et al., 1956). So far no definite morphological changes in the islet tissue have been observed in the few diabetics who have died while receiving tolbutamide (Creutzfeldt, 1956; Ferner and Runge, 1956). Pfeiffer and his colleagues have tried to correlate histological changes in the $\beta$ cells with changes of blood sugar level and pancreatic insulin content. In experiments with calves they have been able to show a transient degranulation of the $\beta$ cells with increase in nuclear volume and a transient reduction of extractable insulin from the pancreas following a single moderate-sized dose of tolbutamide by mouth. The fall in blood sugar concentration closely paralleled these changes. That $\beta$ cell degranulation is a specific response to the hypoglycaemic sulphonylurea compounds is suggested by Creutzfeldt, Detering and Welte (1957). They have shown that large doses of two other sulphonylureas (N-(4-methyl-benzene-sulphonyl) $-\mathrm{N}^{\prime}$-methylcarbamide and $\mathrm{N}$-sulphanilyl-N'-ethylcarbamide) have no effect on the blood sugar level and do not produce changes in the $\beta$ cells.

Perhaps the most compelling evidence that the drugs produce hypoglycaemia by the release of endogenous insulin is provided by Pfeiffer, Renold, Thorn and others who have confirmed the earlier work of Recant and Fischer. They have shown, by assay on the rat epididymal fat pad (Martin, Renold and Dagenais, 1958), that the insulin-like activity of pancreatic vein blood (which is normally higher than peripheral vein blood) increases many times after the administration of hypoglycaemic sulphonylureas to normal dogs. In rats, one group of workers find that the insulin-like activity of peripheral vein blood is increased by carbutamide (Von Holt et al., 1957) and tolbutamide (Kracht et al., 1957). But in humans tolbutamide does not produce a rise of insulin-like activity in the peripheral blood when assayed by the glucose uptake of the rat diaphragm (Renold et al., 1957; Weaver et al., 1958).*

If, then, the sulphonylurea compounds produce hypoglycaemia by stimulating insulin release from the pancreas, it should be possible to demonstrate some of the metabolic effects of increased peripheral glucose utilization in man. After insulin injections, the peripheral arterio-venous glucose difference increases, plasma potassium and phosphate concentrations fall, lactate and pyruvate levels rise and there is an increase of the respiratory quotient. With rare exceptions these changes have not been observed following tolbutamide or carbutamide, although many observations by different

\footnotetext{
*Using a more sensitive rat diaphragm technique Fraser, Joplin and Vallance-Owen have now been able to detect in the peripheral blood of tolbutamidesensitive diabetics a significant rise of insulin-like activity following a single oral dose. They find a good correlation $(r=0.69(p<0.01))$ between the increase of glucose uptake by the diaphragm and the fall of blood sugar concentration.
} 
workers have been made (Purnell et al., r956; Renold et al., 1957, and others). However, such negative findings lose much of their importance once it is realized that these indices of peripheral glucose utilization are relatively insensitive and liable to considerable experimental error. When insulin is given intravenously in doses which mimic the fall of blood sugar level produced by tolbutamide, evidence of increased peripheral utilization is also often inconclusive, especially if the injection is made slowly. Madison and Unger have shown that when insulin is injected into the portal vein (thus simulating endogenous secretion of insulin) little effect on arterio-venous glucose differences can be demonstrated, although equivalent doses of insulin by rapid injection into a peripheral vein are followed by an easily demonstrable increase. Because of these difficulties it is perhaps significant that Goetz et al. (1956) do claim to have shown increased glucose uptake by the tissues following intravenous tolbutamide in high doses. By simultaneous measurement of fore-arm blood flow, Butterfield and his coworkers claim to have found that there is a critical blood sugar concentration below which glucose does not enter cells. This threshold is raised in diabetes and can be lowered by oral tolbutamide if the drug is therapeutically effective.

In intact animals the sulphonylurea compounds increase liver glycogen content without affecting muscle glycogen; single injections of insulin do the reverse. However, if a constant intravenous insulin infusion is given to fasting, intact rats (Dulin and Johnston, 1957), the blood sugar falls, although muscle glycogen remains unchanged. This again emphasizes that the metabolic response to insulin is greatly effected by the route and rate of administration.

(b) Diminished destruction of insulin has been suggested by Mirsky, who has demonstrated inhibition of insulinase in rat liver slices. Vaughan has shown, however, that insulinase is not inhibited by the blood levels reached in man following therapeutic doses of tolbutamide. In intact rabbits Weaver and his co-workers have shown that the rate of degradation of $\mathbf{I}^{\mathbf{1 3 1}}$-labelled insulin (separated from the plasma electrophorectically) is not altered by tolbutamide, and the liver of rats pre-treated with the drug destroy $\mathrm{I}^{131}$-labelled insulin at the normal rate (Williams and Tucker, 1956). The majority of workers have been unable to obtain potentiation of exogenous insulin by the sulphonylureas in severe diabetics or following pancreatectomy in man. However, in depancreatized dogs there is some evidence that large doses of carbutamide or tolbutamide (Houssay et al., 1956; Caren and Corbo, 1957) will allow a reduction of the insulin dose. Diminished des- truction of insulin, therefore, does not appear to be an important effect of the sulphonylureas, but as Mirsky suggests, inactivation of insulinase may be responsible for the slow rise of blood sugar level following tolbutamide-induced hypoglycaemia which contrasts with the rapid rise seen after insulin.

(c) Reduction of hepatic glucose output by a direct action on the liver has been suggested by the majority of workers because the sulphonylurea compounds do not appear to increase glucose uptake by the peripheral tissues in man. There is no doubt that tolbutamide reduces the output of glucose by the liver in humans and in dogs, during fasting and after fructose administration (Renold et al., 1956; Moorhouse et al., 1957) whether measured directly by means of catheterization studies or indirectly by the rate of fall of the specific activity of $\mathrm{C}_{14}$-labelled glucose (Ashmore, Cahill and Earle, 1957; Tarding and Schambye, 1958; Miller et al., 1957; Purnell et al., 1956; Recant and Fischer, 1957).

In vitro, tolbutamide interferes with the conversion of liver glycogen to glucose. Large amounts added to the incubating medium prevent glucose release from rat and rabbit liver slices (Clark et al., 1956; Vaughan, 1956; Berthet et al., 1956). The increased glucose output induced by adrenalin is particularly affected (Vaughan, 1957). Weber an Cantero have shown that tolbutamide inhibit? glucose-6-phosphatase predominantly; phosphohexosisomerase activity is slightly reduced but liver phosphoglucomutase, glucose-6-phosphate dehydrogenase and 6-phosphogluconate dehydrogenase are unaffected. This suggests that in vitro tolbutamide has a specific effect on glucose-6phosphatase, although the concentrations necessary are five to ten times higher than the peripheral blood levels which produce hypoglycaemia in vivo. Liver tissue removed from rats during tolbutamide hypoglycaemia does not show reduced glucose6-phosphatase activity (Ashmore, Cahill and Hastings, 1956) and it should be remembered that many other sulphonamides or sulphonamide derivatives which do not lower the blood sugar will also inhibit liver glucogenic enzymes.

Dulin and Johnston claim that removal of the liver does not prevent the hypoglycaemic response to tolbutamide in dogs, but this work has not been confirmed.* Since the animals need a constant glucose infusion in order to survive, the interpretation of changes of blood sugar level is difficult. However, supporting evidence is reported by Colwell, Colwell and Colwell, who showed that

\footnotetext{
*Sobel et al. (1958) have now confirmed this finding. Moderate doses of tolbutamide produced a similar fall of blood sugar concentration in liverless and intact dogs.
} 
intraportal injections of carbutamide did not cause hypoglycaemia and that injections of tolbutamide into the hepatic artery did not produce a greater fall of blood sugar than peripheral injections. These findings make it difficult to believe that, in therapeutic doses, the sulphonylurea compounds reduce hepatic glucose output by a direct action on the liver and it is possible that this effect may be due largely to increased endogenous insulin secretion. If not, it is difficult to explain why the sulphonylurea compounds are only effective in the presence of an insulin-containing pancreas, although it is conceivable that the metabolic upset following pancreatectomy in some way masks a primary hepatic effect of the drug. However, our knowledge of the hepatic action of insulin is still inconclusive. An increase of hepatic glycogen under the influence of insulin can be demonstrated readily in intact animals provided the insulin is rigorously glucagon-free and no fall of blood sugar is allowed to occur. Dunn and his colleagues, using the rate of decay of the specific activity of Ci4-labelled glucose as an index of hepatic glucose output, have observed a ' plateau' lasting 10 to 20 minutes following ro units of insulin intravenously in unanaesthetized, intact dogs. This indicates suppression of the entry of glucose into the circulation. Their work confirms earlier observations made in humans by Bearn, Billing and Sherlock using catheterization techniques. More recently, however, Mahler and his colleagues by catheter studies in unanaesthetized dogs have failed to obtain evidence of inhibition of hepatic glucose output following insulin injected into the portal vein or splenic artery. They find that when the portal blood sugar concentration falls below $60 \mathrm{mg}$. per $100 \mathrm{ml}$., there is an increased output of glucose from the liver. This does not happen if a similar fall of blood sugar level has been induced by tolbutamide. Tarding and Schambye have also failed to show a reduction of hepatic glucose output following constant intraportal infusions of small amounts of insulin.

In conclusion, although from animal experiments the evidence that the sulphonylureas produce hypoglycaemia by releasing insulin from the pancreas is quite convincing, the only evidence of such a mechanism in man is that juvenile diabetics and pancreatectomized patients do not respond to the drugs.* Reduction of hepatic glucose production appears to be the reason for the fall in blood sugar level after tolbutamide, but whether this is caused pharmacologically by directly inhibiting hepatic glucogenic enzymes or physiologically by an increased output of endogenous insulin, cannot be answered until our knowledge of the hepatic

\footnotetext{
*See footnote on page 250.
}

effect of insulin is more certain. It is possible that both mechanisms may operate and a direct action on the liver cells may enhance the hepatic effect of endogenous insulin.

\section{Clinical Considerations}

The sulphonylurea compounds are only, effective in patients with mild diabetes of the late-onset or adult type; 60 to 70 per cent. of the diabetic population belong to this group. They are not insulin deficient (as defined above) and they have no tendency to develop diabetic ketosis. In contrast, the sulphonylureas are useless in severe diabetes of the juvenile type. These patients are truly insulin deficient and they need daily injections of insulin to maintain health. Giving sulphonylurea compounds at the same time will not usually allow a reduction of the insulin dose, and a labile or ' brittle' diabetic cannot be made more stable.

The majority of patients with mild diabetes of the adult type are obese, and weight reduction with adequate restriction of carbohydrate in the diet will often control their symptoms and hyperglycaemia. There is, however, a small group of middle-aged or elderly diabetic patients, constituting perhaps 5 to ro per cent. of the total diabetic 8 population whose diabetes has developed late in life, sometimes with moderately severe symptoms they have little or no tendency to ketosis, they are often under-weight and their hyperglycaemia cannot be adequately controlled by diet alone. These patients would otherwise require insulin and will benefit most from treatment with the sulphonylurea compounds.

\section{Selection of Patients}

Suitable patients can usually be selected on clinical grounds alone, although this may be difficult if the patient is already taking insulin. Objective tests have, therefore, been devised to assess the likelihood of a good therapeutic response to tolbutamide. At the Joslin Clinic (Marble and Camerini-Dávalos, 1957) a single $3 \mathrm{~g}$. oral dose of tolbutamide is given when fasting; after four hours, patients likely to respond to the drug will have shown a fall of blood sugar (Somogyi-Nelson technique) to I ro mg. per $100 \mathrm{ml}$. or less. Patients with a fasting blood sugar of over $25^{\circ} \mathrm{mg}$. per $100 \mathrm{ml}$. rarely show the requisite fall and are usually unsuitable for treatment with tolbutamide. This observation is confirmed by experience at the Middlesex Hospital, where it is found that tolbutamide seldom reduces the random blood sugar level by more than $150 \mathrm{mg}$. per $100 \mathrm{ml}$. Selection by this method is very stringent and reasonably reliable but some suitable patients will be missed. 
Ducan et al. used the development of ketoacidosis as an index of response to tolbutamide. If ketones appear in the urine eight hours after the last insulin dose, oral therapy is contraindicated, but if no ketones have appeared within 24 hours, tolbutamide will usually be successful. There are, however, some patients unresponsive to tolbutamide who do not easily develop ketosis. Because the value of these short-term tests is limited, the best method of selection is a therapeutic trial. As a general rule tolbutamide should only be considered for patients with mild diabetes who are within ro per cent. of the ideal weight for their height and years (Kemsley, r95 I). Although they may be receiving insulin, obese diabetics can often be controlled by weight reduction and carbohydrate restriction alone once the insulin has been stopped. If such patients are treated with oral hypoglycaemic drugs, weight reduction becomes almost impossible. In patients of normal weight who are taking insulin the insulin dose should be gradually reduced until hyperglycaemia appears. Tolbutamide in divided doses of 1 to $2 \mathrm{~g}$. per day can then be introduced and the insulin dose reduced still further. If the blood sugar level falls, insulin may be reduced again and finally given up entirely. The patient should be seen daily and frequent blood sugar estimations performed. Ketonuria must be watched for carefully. The changeover is best performed in hospital, particularly in those receiving more than 20 units of insulin daily, because some patients rapidly become uncontrolled and insulin treatment has to be resumed at once.

A delayed type of response is seen in some patients. Hyperglycaemia may not respond for several weeks although ketosis does not develop. The blood sugar level then falls slowly and thereafter random blood sugar levels remain satisfactory (Walker et al., 1957).

About 5 to ro per cent. of patients who initially respond well to tolbutamide cease to do so after some months of treatment. Dietary indiscretions will explain a few of these cases, but there are many who appear to develop a genuine resistance to the drug. When assessed in hospital, hyperglycaemia persists despite large doses and a rigid diet; and, the drug can be stopped without any further rise of the blood sugar level. As time passes, increasing numbers of patients who have become resistant are being seen. It may represent an 'exhaustion' of the pancreatic $\beta$ cells due to repeated stimulation, although Pfeiffer has shown that the dose of insulin needed afterwards is no higher than before tolbutamide was begun. Nevertheless, following a period of insulin treatment many of these patients will again respond to tolbutamide.

\section{Toxicity}

As used therapeutically in man, tolbutamide is remarkably non-toxic. At the Joslin Clinic since November 1957 only I.I per cent. of 772 patients have developed side effects sufficiently severe to warrant stopping the drug. Dolger has seen no serious toxic reactions among 500 private patients treated for 3 to 12 months. Tolbutamide may cause gastro-intestinal symptoms such as epigastric pain, nausea and diarrhoea, and in patients with peptic ulcer, their dyspepsia may be aggravated. Beaser reports an old man who perforated an acute duodenal ulcer after three months treatment with large doses ( $2.5 \mathrm{~g}$. per day). Urticarial skin rashes are not uncommon, and a single case of purpura has been reported by Sugar. Flushing of the face may occur after alcohol. Most clinical reports describe abdominal symptoms and skin rashes in I to 3 per cent. of patients, but at the Middlesex Hospital 7 per cent. of I 20 patients have developed these features. Most observers have been unable to detect any significant changes in the white cell count, but leucopenia has been reported from time to time. It is usually transient and no case of agranulocytosis has been recorded. CroslandTaylor has observed a temporary fall in the neutrophil polymorph count by the third week of treatment to under 3,000 per c.mm. in 34 per cent. of 32 patients. In two patients leucopenia has persisted but the neutrophil count has not fallen below 1,500 per c.mm. during the 12 months of treatment.

Repeated liver function studies have been performed by Marble and Camerini-Dávalos and by Sherry and Zeffren. No changes of the serum bilirubin, flocculation tests and bromsulphalein excretion have been seen over a period of 12 to 16 months. A slight rise of serum alkaline phosphatase level has been reported by Marble (1958) but its significance is doubtful. Dolger has given tolbutamide to several patients who had recently recovered from hepatitis or obstructive jaundice without evidence of further liver damage. Nevertheless, in dogs severe liver cell damage does develop; Sirek and his colleagues have shown that large doses of tolbutamide (30 to $100 \mathrm{mg}$. per $\mathrm{kg}$.) given over a period of 14 months produce jaundice, a fall in serum albumin concentration, a rise of alkaline phosphatase, and a prolonged prothrombin time which does not respond to vitamin K.

\section{Dangers}

Tolbutamide should only be used when frequent and detailed observation of the patient is possible. The long-term toxicity is unknown, so that tolbutamide treatment is only justified if hyperglycaemia is adequately controlled. 'A high renal threshold for glucose makes urine sugar testing a 
poor index of blood sugar concentration in many of the diabetics who are suitable for tolbutamide, and, therefore, frequent blood sugar estimations should be performed. Ketoacidosis may occur at the time of changing over from insulin, or it may appear rapidly during the course of an acute infection. Even without ketonuria, serious hyperglycaemia due to acquired resistance may develop insidiously. Hypoglycaemia is very rare. Obesity, with its attendant dangers, develops easily and excessive weight gain can only be avoided by careful supervision of the patient's diet. That the sulphonylurea compounds do directly inhibit enzyme systems in the liver (and possibly elsewhere) is important, because any drug which chronically affects hepatic function would ultimately be expected to damage the liver cells. It is too early to say whether the incidence of ' degenerative' complications of diabetes mellitus will be affected by treatment with tolbutamide. Better control of hyperglycaemia will presumably tend to reduce the risk of complications but any drug which increases the tendency to haemorrhage must be used with great caution, particularly in patients with retinopathy. Carbutamide increases capillary fragility (Phemister, 1957), but careful studies by Marx have failed to reveal any difference in the incidence of haemostatic abnormalities between insulin-treated and tolbutamide-treated diabetes.

\section{Chlorpropamide (P.607, Diabinese)}

This new and highly potent hypoglycaemic sulphonylurea compound was discussed at a meeting of the New York Academy of Sciences in September 1958. Chemically it is I-propyl-3p-chlorobenzene-sulphonylurea and it has the following formula:

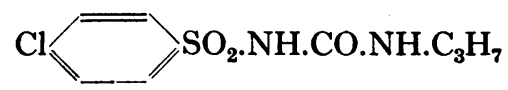

In contrast to tolbutamide it has a chloride ion in the para position on the benzene ring and a propyl instead of a butyl group as the aryl radical.

Absorption from the gut is rapid and maximal blood levels are reached in two to four hours. It is not broken down into an inactive metabolite like tolbutamide and is very slowly excreted in the urine. The biological half-life is about 36 hours. This explains why, weight for weight, chlorpropamide has a much more potent hypoglycaemic effect than tolbutamide. Consequently the dose is much lower and good control can usually be obtained with 200 to $500 \mathrm{mg}$. daily as a single dose.

Animal studies indicate that chlorpropamide acts in a similar fashion to tolbutamide (e.g. the presence of the pancreas is essential) and, like the latter, it is only effective in patients with mild diabetes of the adult type.

Whether chlorpropamide has any clinical advantage over tolbutamide is still undecided. The drug is certainly more potent and the blood sugar level may be reduced by 200 to $300 \mathrm{mg}$. per $100 \mathrm{ml}$. Generally, however, patients unresponsive to tolbutamide will not do better on chlorpropamide, although diabetics with acquired resistance to tolbutamide may respond.

Side effects are quite common with high doses but rare with small doses. Prolonged hypoglycaemia is an important danger and, like the hypoglycaemia of the long-acting insulin preparations, it may only respond slowly to glucose administration. An intrahepatic obstructive jaundice of the type seen with chlorpromazine may develop even with small doses and a curious ataxia with muscle weakness (not due to hypoglycaemia) has been described following large doses of chlorpropamide. Gastro-intestinal side effects are less common compared with tolbutamide but an antabuse-like effect after drinking alcohol may occur.

\section{Phenethylbiguanide (DBI)}

The hypoglycaemic effect of this compound was described by Unger, Freedman and Shapiro in 1957. It is not a sulphonylurea and structurally resembles synthalin. Chemically it has the following formula:

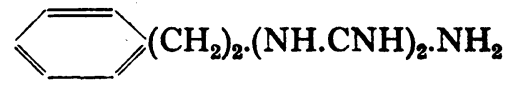

The mode of action is quite different from the sulphonylurea compounds, because the drug is effective in animals with severe alloxan diabetes and also in some human diabetics of the juvenile type. In vitro it increases glucose uptake by the rat diaphragm but the muscle glycogen content decreases, there is a marked increase of lactic acid production and oxygen consumption falls (Williams et al., 1957). This suggests that DBI stimulates anaerobic glycolysis by inhibiting oxidative enzyme systems. With doses of 150 to $200 \mathrm{mg}$. per day Krall and his co-workers have shown that the drug is effective without insulin in many adult diabetics and occasional children. No serious toxic effects have been encountered and repeated liver function studies (over a period of over 18 months in some cases) have not shown any abnormality. However, the majority of patients experience intolerable anorexia, nausea, vomiting and diarrhoea in doses greater than $200 \mathrm{mg}$. per day.

This slender margin between the therapeutic dose and doses which produce severe side effects means that the drug is unlikely to be used extensively although Krall et al. have shown that, 
combined with insulin, DBI will make a labile or 'brittle' diabetic more stable. This may prove to be the main clinical application of the drug.

\section{BIBLIOGRAPHY}

ALLEN, F. M. (1927), f. Amer. med. Ass., 89, 1577

ASHMORE, J., CAHILL, G. F., and HASTINGS, A. B. (1956), Metabolism, 5, 774

ASHMORE, J., CAHILL, G. F., and EARLE, A. S. (1957), $A n n$. N.Y. Acad. Sci., 7I, 131.

ASHWORTH, M. A., and HAIST, R. E. (1956), Canad. med. Ass. F., 74, 975.

BAIRD, J. D., and DUNCAN, L. J. P. (1957), Scot. med. F., 2, 341. BEARN, A. G., BILLING, B. H., and SHERLOCK, S. (1953), Ciba Foundation Colloquia on Endocrinology, 6, 250 .

BEASER, S. B. (1957), Ann. N.Y. Acad. Sci., 71, 264.

BERTHET, J., SUTHERLAND, E. W., and MAKMAN, M. H. (1956), Metabolism, 5, 768 .

BERTRAM, F. (1927), Dtsch. Arch. klin. Med., 158, 76.

BEST, C. H., HAIST, R. E., and RIDOUT, J. H. (1939), 7 . Physiol. (Lond.), 97, 107.

BORNSTEIN, J., and LAWRENCE, R. D. (1951), Brit. med. F., i, 732 .

BUTTERFIELD, W. J. H., and THORNTON, R. H. S. (1957), Clin. Sci., 16, 679.

BUTTERFIELD, W. J. H., KELSEY FRY, I., and HOLLING, H. E. (1958), Diabetes, $7,449$.

CAMPBELL, J., HAUSTER, H. A., MONROE, J. S., and DAVIDSON, I. W. F. (1953), Endocrinology, 53, 134 .

CAREN, R., and CORBO, L. (1957), F. clin. Invest., 36, 1546.

CLARK, D. W., DAVIDSON, M. SCHÖNBAUM, E., and SENMAN, H. (1956), Canad. med. Ass. F., 74, 966.

COLWELL, A. R., COLWELL, J. A., and COLWELL, A. R. (1957), Ann. N.Y., Acad. Sci., 71, 125.

CREUTZFELDT, W. (1956), Dtsch. med. Wschr., 81, 94I.

CREUTZFELDT, W., DETERING, L., and WELTE, $O$. (1957), Ibid., 82, 1564

CROSLAND-TAYLOR, P., personal communication

DOLGER, H. (1957), Ann. N.Y. Acad. Sci., 71, 275.

DULIN, W. E., and JOHNSTON, R. L. (1957), Ibid., 71, 177.

DULIN, W. E., and MILLER, W. L. (1958), Proc. 18th Ann. Meet Amer. Diab. Ass.

DUNCAN, G. G., LEE, C. T., and KENT YOUNG, J. (1957), Ann. N.Y. Acad. Sci., 71, 233.

DUNN, D., FRIEDMANN, B., MAASS, A. R., REICHARD, G., A., and WEINHOUSE, S. (1957), f. biol. Chem., 225, 225

FAJANS, S. S., LOUIS, L. H., SELTZER, H. S. GITTIER, R. D., HENNNES, A. R., WẢJCHENBERG, B. L., ACKERMAN, I. P., and CONN, J. W. (1956), Metabolism, 5, 820 .

FERNER, H., and RUNGE, W. (1956), Dtsch. med. Wschr., 81, 33 I.

FRANKE, H., and FUCHS, J. (1955), Ibid., 80, 1449 .

FRANK, E., NOTHMAN, M., and WAGNER, A. (r926), Ibid. 52, $2067,2107$.

FRITZ, I. B., MORTON, J. V., WEINSTEIN, M., and LEVINE, R. (1956), Metabolism, 5, 744.

GESSLER, C. J., HALSTED, J. A., and STETSON, R. P. (1939), F. clin. Invest., 18, 715 .

GRAHAM, G., and LINDER, G. C. (1928), Quart. F. Med., 21, 509.

GOETZ, F. C., GILBERTSON, A. S., and JOSEPHSON, V (1956), Metabolism, 5, 788 .

HUGH-JONES, P. (1955), Lancet, ii, 89r.

HOUSSAY, B. A., and PENHOS, J. C. (1956), Metabolism, 5, 727.

HOUSSAY, B. A., PENHOS, J. C., URGOITI, E., TEODOSIO, N., APELBAUM, J., and BONKETT, J. (1957), Ann. N.Y. Acad. Sci., 71, 25.

JANBON, M., LAZERGES, P., and METROPOLITANSKI, J. H. (1942), Montpellier Méd., 22, 489 .

JANBON, M., CHAPTAL, J., VEDEL, A., and SCHAAP, J. (1942), Ann. N.Y. Acad. Sci., $44 \mathrm{I}$

KEMSLEY, W. F. F. (1951), Ann, Eugen. (Camb.), 16, 316.

KIRTLEY, W. R. (1957), Diabetes, 6, 72.

KRACHT, J., KRONER, B., VON HOLT, L., and VON HOLT, C. (r957), Ibid., 6, 380 .

KRALL, L. P. and CAMERINI-DAVAlOS, R. (1957), Proc. Soc. exp. Biol. (N.Y.), 95, 345 .

LANG, S., and SHERRY, S. (1956), Metabolism, 5, 733.

LOUBATIERE, A. (1957), Ann. N.Y. Acad. Sci., 71, 4 (review).

MADISON, L. L., and UNGER, R. H. (i958), f. clin. Invest., 37, 631 .

MAHLER, R., SHOEMAKER, W. C., and ASHMORE, J. (1058), 'Symposium on the Mechanism of Action of Insulin'. (1958), Insulin Manufacturers), London.
MARBLE, A., and CAMERINI-DAVALOS, R. (1957), Ann. N.Y. Acad. Sc., 71, 239.

MARBLE, A. (1958), Med. Clin. N. Amer., 42, 1163.

MARTIN, D. B., RENOLD, A. E., and DAGENAIS, Y.M Internat Diab. Fed. Dusseldorf Communic 35

MARX, R., STICH, W., and EHRHART, H. (1957), Disch. med. Wschr., 82, 1533

MCGAVACK, T. H., SEEGERS, W., HAAR, H. O., ENZINGER, J., and ERK, V. O. (1957), Ann. N.Y. Acad. Sci., 7I, 268.

MILLER, M., CRAIG, J. W., MACKENSIE, M. S., DRUCKER, W. R., CAMMARN, M., and WOODWARD, H. (1957), Ibid., 7I, $5 \mathrm{I}$.

MIRSKY, A. I., PERISUTTI, G., and GITELSON, W. (1957), Ibid., 71, 103.

MOORHOUSE, J. A., KARK, R. M., and GELLMAN, D. D. (1957), Ibid., 7r, 97.

PFEIFFER, E. F. (1957), 7. Endocr., 15, xlviii.

PFEIFFER, E. F., STEIGERWALD, H., SANDRITTER W BANDER, A., MAGER, A., BECKER,' U., and RETIENE, $\mathrm{K}$. (1957), Med. Klin., 52, 968.

PFEIFFER, E. F., STEIGERWALD, $H$., SANDRITTER $w$, BANDER, A.,'MAGER, A., BECKER,' U., and RETIENE, K.' (1957), Dtsch. med. Wschr., 82, 1568 .

PFEIFFER, E. F., RENOLD, A. E. MARTIN, D. B. DAGENAIS, Y. M., MEAKIN, J. 'ं., NELSON, D. H., SHOEMAKER, G., and THORN, G. 'W. (I958), Internat, G Diab. Fed. Dusseldorf Communic, 75.

PHEMISTER, J. C. (1957), Brit. med. F., i, 199.

POZZA, G., GALANSINO, G., FOA, P. P. (1956), Proc. Soc. exp. Biol. (N.Y.), 93, 539.

PURNELL, R., ARAI, Y., PRATT, E., HLAD, C., and ELRICK, H. (1956), Metabolism, 5, 778 .

RECANT, L., and FISCHER, G. L. (1957), Y. clin. Invest., 36, 922.

REID, J., MACDOUGALL, A. I., and ANDREWS, M. M. (1957), Brit. med. Э., ii, 1071 .

RENOLD, A. E., WINEGRAD, A., FROESCH, E. R., and THORN, G. W. (1956), Metabolism, 5, 757.

RENOLD, A. E., MARTIN, D. B., BOSHELL, B, R, $\vec{\theta}$ THORN, G. W. (1957), Ann. N. Y. Acad. Sci., 71, 71., ang of

SHERRY, S., ZEFFREN, J. L., BRAVERMAN, A. E., and DREY, N. (1957), Ibid., 71, 249.

SIREK, A., SIREK, O., MONKHOUSE, F. C., LOGOTH TOPOULOS, J., and BEST, C. H. (1958), Internat. Diaț: Fed. Dusseldorf Communic., 189.

STOWERS, J. M., MAHLER, R. F., and HUNTER, R. B. (1958), Lancet, i, 278.

SUGAR, S. J. N. (1957), Ann. N.Y. Acad. Sci., 71, 256.

TARDING, F., and SCHAMBYE, P. (1958), Endokrinologie, 36, 222.

UNGER, G., FREEDMAN, L., and SHAPIRO, S. L. (1957), Proc. Soc. exp. Biol. (N.Y.), 95, 190.

UNGER, R. H., and MADISON, L. L. (1958), Diabetes, 7, 445.

VAUGHAN, M. (1956), Science, 123, 885.

VAUGHAN, M. (1957), Ann. N.Y. Acad. Sci., 71, 112.

VON HOLT, C., VON HOLT, L., and KRONER, B. (1956), Э Naturwiss., 43, 162.

VON HOLT, C., VON HOLT, L., KRACHT, J., KRONER, B. and KUHNẢU, J. (1957), Science, 125, 735.

WEAVER, J. A., PROUT, T. E., SCOTT, G. W., and ASPER, S. P. (1958), Brit. med. $\mathcal{F} .$, i, 425

WEBER, G., and CANTERO, A. (1958), Metabolism, 7, 333.

WALKER, G., SLATER, J. D. H., WESTLAKE, E. K., and NABARRO, J. D. N. (1957), Brit. med. $\mathcal{F}$., ii, 323.

WICK, A. N., BRITTON, B., and GRABOWSKI, R. (1956), Metabolism, 5, 739 .

WILLIAMS, R. H., and TUCKER, B. W. (1956), Ibid., 5, 801.

WILLIAMS, R. H., TYBERGHEIN, J. M., HYDE, P., and O NEILSON, R. L. (1957), Ibid., 6, 311 .

WRENSHALL, G. A., and BEST, C. H. (1956), Canad. med. Ass. $\mathcal{Y}, 7_{4}, 068$

\section{References to footnotes}

CAHILL, G. F., HASTINGS, A. B., and ASHMORE, J. (1957), Diabetes, 6, 26.

FRASER, T. C. R., JOPLIN, G. F., and VALLANCE-OWEN, J. (1959), Personal communication.

LUNDBAEK, K., NIELSEN, K., and RAFAELSEN, O. J. T (1958), Lancet, i, 1036.

RECANT, L., and FISCHER, G. L. (1957), Ann. N.Y. Acad. Sci., 71, 62.

SOBEL, G. W., RODRIGUEZ-INIGO, J., MORTON, J. V., and LEVINE, R. (1958), Metabolism, 7, 222. 
sufficient to prevent softening of glands, even when it is continued for more than a year. Originally streptomycin and P.A.S. were used, and later I.N.H. and P.A.S. The latter combination can be given for long periods without difficulty. The effect of giving chemotherapy to children with firm glands recently infected is interesting, there is an immediate response which is proportional to the original size of the glands. Thus in a febrile child with an acute reaction, and a large mass of glands with much peridenitis, the temperature falls rapidly, and the swelling shrinks, often resolving into two or more discrete glands. In a child with a small gland and little change in general health or bodily reaction the change is correspondingly less. But all children improve in health and well-being and all recently infected glands show some reduction in size when first treated. This improvement continues for about three to four weeks and then stops, leaving a firm, movable, painless gland. If the chemotherapy is continued, the gland may remain in this state for many months but those we have observed have softened ultimately. Once softening occurs, skin involvement is inevitable and then the chance of achieving a good cosmetic result has largely gone.

In looking after a child with recent tuberculous infection of glands I therefore use chemotherapy and continue as long as necessary until the first sign of secondary enlargement of the gland occurs. Then I advise removal of the whole gland and its immediate neighbours by careful local dissection. No attempt is made to remove all infected glands, for infection has spread far down the lymphatic chain, but great care is taken with the final suturing of the wound. Chemotherapy is continued for at least a year after the infection. The prolonged chemotherapy has two purposes: to help to avoid further local abscesses and to prevent haematogenous lesions in other organs. Chemotherapy is just as necessary when the lymph glands are superficial and visible as it is when the infection is pulmonary or mesenteric.

Streptomycin ( $45 \mathrm{mg}$. per kilo, $20 \mathrm{mg}$. per I lb. body weight, with a maximum dose of $\mathrm{I}$ g. per day) and I.N.H. (20 mg. per kilo, maximum $400 \mathrm{mg}$.) are used to cover the operation and until the wound is firmly healed. The daily injection of streptomycin is then stopped and P.A.S. (125 mg. per I lb., $300 \mathrm{mg}$. per kilo) is given instead and continued for at least a year.

If the glands are soft when first seen, the situation is not so favourable, but, whether infection is recent or old, the general problem is the same and chemotherapy should be given as described above. When there is calcium present and infection has been present for a considerable time there is not the same risk of new haematogenous spread but I.N.H. and P.A.S. should be given for six months.

The basic trouble when the gland has softened is that it cannot be removed as a whole, and if caseous material is left at the site of the abscess then there is always a risk of subsequent abscess formation. Unless the contents of the gland are exceptionally fluid, mere incision is not likely to remove all caseous material; for this reason other methods, such as curettage or expression, have been used, and more recently Lincoln (1957) has used enzyme irrigation to achieve the same purpose. If the caseous material can be removed healing will follow, but the final appearance of the scar depends upon the amount of skin loss.

The early recognition and effective treatment o tuberculous lymphadenitis in this way can reduce the length of illness, the chance of complications and avoid the pigmented scars seen a generation ago.

In conclusion, therefore, it can be seen that the situation with regard to peripheral tuberculous lymphadenitis is changing rapidly, new cases are becoming less and less common as the sources of infection are brought under control, but old cases infected some time ago continue to present for treatment. Peripheral tuberculous lymphadenitis is also still to be seen in adults but, as I indicated at the beginning of this paper, its natural history seems different from that of tuberculous adenitis in childhood and it may require different treatment.

\section{BIBLIOGRAPHY}

ANASTASIADES, A. A., TSIKOUDAS, E. C., LINCOLN, E. M., and DALY, J. F. (1957), Amer. Rev. Tuberc., 76, 588 . MILLER, F. J. W., and CASHMAN, J. M. (1955), Lancet, i, 1286. MILLER, F. J. W., and CASHMAN, J M. (1958), Ibid., MILLER, F. J. W. (1953), Ibid., i, 3.

SMITH, C. M. (1958), Med. Offr., 99, 45.

\section{Erratum May Issue}

We apologize for the illustration appearing in Dr. J. D. H. Slater's article on 'Oral Hypoglycaemic Drugs' which we regret was included in error. 